\title{
Removal of American mink (Neovison vison) from the Uists, Outer Hebrides, Scotland
}

\author{
S. S. Roy - A. L. M. Chauvenet · P. A. Robertson
}

Received: 5 August 2014/ Accepted: 15 June 2015/Published online: 24 June 2015

(C) The Author(s) 2015. This article is published with open access at Springerlink.com

\begin{abstract}
Since escaping from fur farms in the 1950s, American mink had colonised the $2800 \mathrm{~km}^{2}$ archipelago of the Outer Hebrides of Scotland. Between November 2001 and June 2006 the species was removed from a total of $850 \mathrm{~km}^{2}$ of the southernmost islands, collectively named the Uists, as part of a pilot study exploring the feasibility of large scale eradication throughout the archipelago. Animals were also controlled in neighbouring South Harris $\left(255 \mathrm{~km}^{2}\right)$ to reduce the risk of recolonisation. The project used two main methods, the operation of coastal and riparian cage traps; and trapping at breeding dens located using trained dogs. In the Uists this resulted in 100,824 trap nights over 4 years. Den searches were carried out over 500 handler-days. Overall a total of 228 mink was
\end{abstract}

S. S. Roy $(\bowtie)$ · A. L. M. Chauvenet · P. A. Robertson National Wildlife Management Centre, Animal and Plant Health Agency, Sand Hutton, York YO41 1LZ, UK e-mail: sugotoroy@gmail.com

Present Address:

S. S. Roy

International Union for the Conservation of Nature, 28

Rue Mauverney, 1196 Gland, Switzerland

\section{A. L. M. Chauvenet}

School of Biological Sciences, University of Queensland, Brisbane, QLD 4072, Australia

\section{P. A. Robertson}

Centre for Wildlife Management, School of Biology, Newcastle University, Newcastle upon Tyne NE1 7RU, UK caught in The Uists, with the last capture in March 2005. After this date, despite a further 7 months of intensive trapping and searching effort, no further signs of mink were found and they were considered likely to have been removed from this region. In the buffer area of South Harris, 41,674 trap nights over 4 years resulted in 240 captures with few animals being caught by the end of the project. This effort greatly reduced the risk of recolonisation from this region, although there was still a possibility of extant isolated populations remaining within the region, particularly on offshore islets, which would then be detected and trapped by a follow up programme. An adaptive management process resulted in significant increases in trapping efficiency. Improvements included optimisation of trap spacing and the frequency and duration of trap-line operation; improvements in the cage designs and use of lures. The protocols developed here were used in the subsequent eradication campaign in the remainder of the Outer Hebrides.

Keywords Invasive alien species - Removal · Wildlife management · Mink · Outer Hebrides

\section{Introduction}

Habitat loss and non-native species are considered the two most important threats to global biodiversity (Vitousek et al. 1997). Invasive carnivores have caused substantial biodiversity loss, particularly on islands (Nogales et al. 2013). The American mink 
Neovison vison is a widely distributed invasive carnivore, occurring in 28 European countries, The eradication of invasive Mustelids in general can be challenging (King et al. 2009), and most mink control operations in Europe are long-term control operations rather than eradications, for example in Iceland (Bonesi and Palazon 2007) or at a local catchment level in England (Reynolds et al. 2004).

Mink populations were established on the Outer Hebrides of Scotland when animals escaped, or were deliberately released, from fur farms in Carloway, Dalmore and Steinish on the Isle of Lewis in the 1950s (Fig. 1) (Angus 1993; Cuthbert 1973). Mink then spread steadily southwards through Harris, and although attempts were made to stop them from colonising the Uists [North Uist, Benbecula and South Uists (Angus 1993)], they were found in North Uist in the 1990s and a population was discovered in South Uist in 2002. Thus, they had successfully established populations across the entire archipelago of $2800 \mathrm{~km}^{2}$ within 50 years of their initial release.

The Outer Hebrides support internationally important habitats and bird populations. Mink have been reported to have severe impacts on bird populations (Clode and MacDonald 2002), in particular on groundnesting species, and fish populations (Areal and Roy 2006; Bilsby 1999, 2001). In addition to direct impacts on biodiversity, there are financial concerns in the Outer Hebrides as eco-tourism, aquaculture, game fishing and crofting are important elements of the local economy to the estimated value of up to $£ 30$ million annually (ERM 1996; James 2000).

\section{Methods and results}

The Hebridean Mink Project was established with the objective of removing mink from North Uist, Benbecula and South Uist and to reduce mink density from neighbouring South Harris to minimise recolonisation of the Uists. Descriptions of the project can be found in Moore et al. (2003) and Roy (2012). The control site in the Uists comprised approximately 356 islands and skerries totalling $850 \mathrm{~km}^{2}$. The area contained a complex mixture of freshwater and saltwater habitats, with $1116 \mathrm{~km}$ of coastline, $2416 \mathrm{~km}$ of loch shore and $189 \mathrm{~km}$ of rivers and streams, all of these are key habitats for mink, particularly along the west coast of Scotland and its offshore islands (Ireland 1990).
Prior to start of the project, a review of existing data on the key mink life history variables was undertaken, and a simple population model constructed including biologically plausible assumptions where direct information was absent (Moore et al. 2000). These included recorded mink densities and literature on reproductive rates and survival (Dunstone and Birks 1983). This review formed the basis of a successful bid for EU LIFE funding, and guided the initial planning and logistics of the control programme. However, the project began without detailed understanding of the number of mink present in the areas, the effort required to achieve their eradication or the most effective methods. This work therefore adopted an adaptive management approach (Williams 2011), analysing and interpreting the results as the work progressed to identify possible refinements.

Trapping began in November 2001 while searching for denning animals using dogs was added as a secondary method from spring 2003. A total of 2545 live capture cage traps was dug into the ground during the first 3 months of the project, although a total of $10 \%$ was open at any one time, with the remainder left locked shut to prevent captures in traps that were not being set and monitored daily. Unset traps with closed doors were also easier to find than those with doors locked open, when they were set later (Roy 2012). This approach reduced the manpower needed to repeatedly set, lift and relocate traps, relying instead on large numbers of pre-located traps being used in rotation. The location of each trap was recorded using GPS. Traps were set and baited and were in use for a 1 or 2 week period, when they were checked daily. On average each trap was in use during four or five separate periods per year. A total of 100,824 trap nights of effort was deployed during the project. Starting in spring 2003, three trained dogs (collies and spaniels) were used to locate active den sites, followed by intensive trapping in the immediate vicinity of the breeding den. Approximately 500 days of effort were put into dog based searches although effort was not formally recorded as they were used opportunistically, and covered large areas by quartering the land. The time spent on the ground, and the area covered, was highly variable; although effort was most concentrated during the spring and summers of 2003-2005, dogs accompanied handlers throughout the year, and mink presence was verified by handlers interpreting their behaviour. Trappers also recorded all presence of sign 


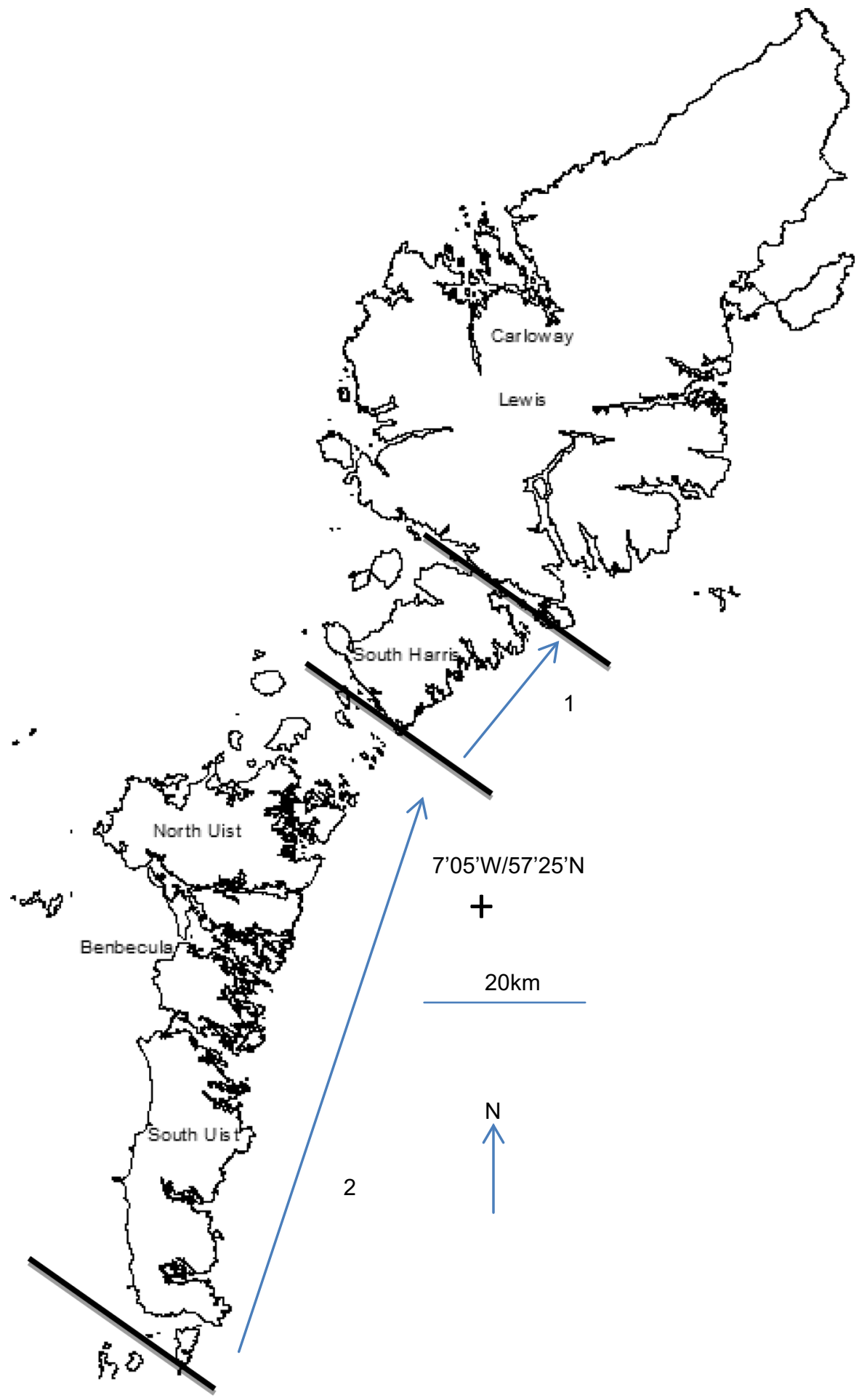

Fig. 1 A map of the Outer Hebrides showing Carloway, where the fur farms originally were, the buffer zone of Harris (1) and the removal zones of the Uists (2) 
such as scats and prey remains, especially along the edge of water courses. The effort involved in the collection of these additional data could not be recorded as it was carried out as trappers moved from trap to trap along their daily routes. Sightings recorded by the public were also recorded and traps in the area were often opened to catch these animals. These provided additional data on mink presence/absence.

This programme relied on traps and dog searches. Other techniques were considered or have become available subsequently. Techniques have been available for tracking mustelid movements for many decades (King and Edgar 1977). These provide the basis for techniques, such as mink rafts which have proved to be effective in some habitats, for example slow moving waters (Reynolds et al. 2004). Given the fast flowing or tidal habitats on the Western Isles, we did not use this method. Since the completion of this phase of the campaign, other tools have emerged, such as self-reporting traps (http://www.minkpolice.com). These systems enable trappers to set large numbers of traps and service only those that have made a capture, greatly enhancing efficiency at landscape scales.

Captured animals were humanely dispatched with a shot to the brain stem using .22 calibre air pistols. They were then sexed and aged broadly into juveniles and adults based on tooth wear combined with the presence or absence of milk teeth (Yamaguchi et al. 2002). For the purposes of simple categorization as adult and juvenile, this was deemed sufficient. A total of 228 mink was captured during the course of the Uist project, 191 during standard trapping and 37 (including 20 dependent young) during trapping associated with dog searches. The last capture occurred on 23 March 2005. After that date, a total of 5567 further trap nights and a summer of dog searches did not produce further captures or signs of mink, in particular we found no evidence of young being produced which would have suggested the presence of trap shy breeding individuals. This supports a conclusion that the programme had been successful in removing all breeding activity, but with the possibility that isolated individuals may have remained, for example on offshore islets. This work was followed by a more extensive eradication programme and expending effort to improve the confidence in local eradication at the end of this pilot study would not have been a productive use of effort. In South Harris, 248 mink were captured, of which 230 derived from trapping.
The Harris data did not demonstrate a decline in captures as occurred in the Uists, as would be expected as this region was intended to act as a buffer zone bordering a large, untrapped population to the north.

The trapping effort was between 20,000 and 31,000 trap nights per year during each of the 4 years of the project in the Uists. However, catch per unit effort rose between the first and 2 years before falling away in subsequent seasons (Table 1). It was mainly during the first 2 years of the work that active steps were taken to improve trap efficacy. As Uist mink numbers were expected to have declined in each year of the project, the observed increase in catch per unit effort thus suggests an improvement in trap efficiency as the work progressed, at least between the first and second years, rather than an increasing mink population. The rising capture rate in the buffer zone in Harris also suggested an improvement in trapping efficacy. The reduction seen in capture rates, and the changes seen in population age and sex structure are likely to reflect a decreasing population caused by the campaign. This was corroborated by records of scats and signs collected by trappers and associated sighting reports collected from the public. Captures made as a result of sightings resulted in seventeen captures in 2003, and four in 2004. All reported sightings resulted in a capture. As further evidence, all carcasses were aged and sexed and researchers looked for clusters of juvenile captures or placental scars and corpora lutea in females to provide evidence of breeding events and therefore presence of males. There was no evidence of breeding events from the Uists recorded beyond February 2004, although there was in Harris.

Initially, the trappers had different levels of experience in locating and setting traps. The trappers were therefore rotated between different trap lines, such that each trap was seen, inspected and adjusted by a number of different trappers through the course of the first year. In this way, the experienced trappers inspected all of the traps and had the opportunity to improve their fine setting. These changes included better siting of traps on animal runs, for example, placing the trap door facing downstream when set on a riverbank, on the expectation that mink will run upstream, but swim downstream in fast flowing rivers. Then, replacing the original wire mesh trap doors with solid galvanised metal ones also allowed trappers to check traps from a distance, saving time and minimising disturbance (Roy 2012). These changes all took 
Table 1 The numbers of trap nights, mink captures and trap success in the Uists and South Harris during the course of the project

\begin{tabular}{|c|c|c|c|c|c|c|c|c|}
\hline \multirow[t]{2}{*}{ Year beginning } & \multicolumn{2}{|c|}{ Trap nights } & \multicolumn{2}{|c|}{$\begin{array}{l}\text { Mink captured by } \\
\text { trapping }\end{array}$} & \multicolumn{2}{|c|}{$\begin{array}{l}\text { Mink captured per } 1000 \\
\text { trap nights }\end{array}$} & \multicolumn{2}{|c|}{$\begin{array}{l}\text { Mink captured by dog searches, } \\
\text { (dependent young in brackets) }\end{array}$} \\
\hline & Uist & Harris & Uist & Harris & Uist & Harris & Uist & Harris \\
\hline Sept 2001 & 22,155 & 15,350 & 42 & 73 & 1.85 & 4.76 & 0 & 6 \\
\hline Sept 2002 & 26,357 & 13,213 & 80 & 54 & 2.97 & 4.08 & $12(18)$ & $1(2)$ \\
\hline Sept 2003 & 30,064 & 10,325 & 56 & 64 & 1.86 & 6.20 & $4(2)$ & (3) \\
\hline Sept 2004 & 20,037 & 2755 & 13 & 38 & 0.65 & 13.79 & 1 & $3(1)$ \\
\hline Sept 2005 & 1114 & 76 & 0 & 1 & 0 & 13.15 & 0 & 0 \\
\hline Total & 100,824 & 41,674 & 191 & 230 & 1.89 & 5.51 & 37 & 18 \\
\hline
\end{tabular}

Years run from the beginning of September

place during the first full year of the project and while they are likely to have significantly increased trapping efficiency, it is difficult to fully quantify their individual or combined effects.

Traps were originally set by the field team, digging traps into set positions chosen by each trapper along a route that could be walked once per day. Typically this involved 30-50 traps along a distance of 4-10 km dependent on terrain. Traps were primarily set along the edge of water features, including streams, loch shores or the coast. By the end of 2002, 1125 separate trap locations had been established. Assuming each trap had an effective catch radius of $250 \mathrm{~m}$, based on the typical home range size of a mink (Dunstone and Birks 1983), these traps covered $30.8 \%$ of the available $3731 \mathrm{~km}$ of water feature edge in the Uists. The $250 \mathrm{~m}$ trapping radii also overlapped between neighbouring traps, such that $35.6 \%$ of the trapped areas were covered by more than one trap. During 2003 this trap distribution was reviewed and effort redistributed to increase the number of trap locations, raise coverage of the water features while avoiding increases in overlap. By 2004 the total trap locations in the Uists had risen to 2466 covering $83.1 \%$ of the water features with only a small increase in overlap to $40.5 \%$.

Improvements continued in subsequent years, including reducing the length of time over which trap lines were operated, reduced from two consecutive weeks to one as most mink were found to be caught in the first few days after traps were initially set. In addition, the traps were originally baited with fish, but subsequent paired comparisons showed that traps baited with commercially purchased mink scent gland extract (Kishel Scents and Lures, Saxonburg, USA) had significantly higher capture rates (Roy et al. 2006). These lures were used routinely after May 2003.

After the first year of trapping, it was clear that there was a significant seasonal component to trap success, in particular success was highest during mating seasons (January-March) and dispersal periods (July-September) as has been reported elsewhere (Birks and Linn 1982; Dunstone and Birks 1983; Ireland 1990). Trapper effort was increasingly concentrated during these period, extra staff (up to 20) were drafted in for intense short-term trapping efforts, contracts were changed to give seasonal flexibility while staff were encouraged to take breaks during the other months. Between September 2001 and August $2003,10.5 \%$ of the annual trapping effort in the Uists was conducted during July to September, after this date, this rose to $19.7 \%$ over the remainder of the project reflecting this changed focus.

As the mink population declined, some regions failed to produce mink captures despite repeated trapping. There was a need to maintain some trapping effort in these regions to ensure no mink remained, but effort was better concentrated in the areas where captures were still being produced. Starting in 2002 a system of setting traps at low densities along roadsides, but keeping them set on a permanent basis was introduced. This focussed on regions with a good road network but where mink had not been observed for some time, allowing a large number of traps to be checked daily from a vehicle by a single trapper. Three percent of the animals caught in 2002 resulted from this technique, falling to $0.5 \%$, and then zero in subsequent years. A similar approach was used on the 
small islands between the Uists and South Harris during 2003, checking selected traps by boat on sites likely to act as 'stepping stones' for dispersing mink from the north. This led to significant savings in manpower and travel costs (Roy 2012).

As the work proceeded on the Uists there was a pronounced change in the sex ratio of captures. Excluding dependent young; before spring 2004, $60.2 \%$ of 156 captures were of females, after that date it rose to $86.8 \%$ of 38 captures. We pooled captures into quarters within each year, corresponding to winter, spring, summer and autumn, and found a significant positive increase in the female to male ratio of captured individuals on the Uists (Mann-Kendall trend test, $\tau=0.477, p=0.03$; Fig. 2). The age ratio of captures in this area also appeared to change: the last free-living juvenile was captured in the Uists in spring 2004, after that date, with the exception of a single dependent kit caught at a denning site; all 11 captures were of adults. However, we found no evidence of a significant change in the age ratio of captured individuals within annual quarters (MannKendall trend test, $\tau=-0.067, p=0.78$; Fig. 3). The buffer zone on Harris showed much less marked fluctuations in both the age and sex ratio of captures; we found no significant trends in the female to male ratio, and juvenile to adult ratio of captured individuals within quarters in this area (Mann-Kendall trend tests; sex ratio: $\tau=-0.132, p=0.58$; age ratio: $\tau=0.183 p=0.48$; Figs. 2, 3).

Traps were normally placed along water features; either coast, loch shore or river. In many cases traps were placed where these features intersected. For analysis, we therefore pooled captures at lochs and rivers into one category, representing inland water; for captures intersecting between coast and inland features, we created a third category of mixed habitat. Captures in each habitat type were once again pooled within annual quarters (Fig. 4). To correct for effort, we then calculated the catch per effort by dividing the number of captures in each habitat per quarter by the number of trap nights (Fig. 5). For the Uists, we found that relative trapping success significantly decreased in coastal habitat over time (Mann-Kendall trend test, $\tau=-0.498, p=0.012$ ) but found no significant change for relative trapping success in the inland and mixed habitats (inland: $\tau=0.211, p=0.30$; mixed: $\tau=-0.193, p=0.35)$. Similar trends were found in the buffer zone on Harris with a significant decrease of catch per effort over time in the Coast habitat ( $\tau=-0.4, p=0.04$ ) but not the others (inland: $\tau=0.219, p=0.29$; mixed: $\tau=-0.211 p=0.28$ ). These findings suggest an underlying change in mink distribution as the populations were reduced.

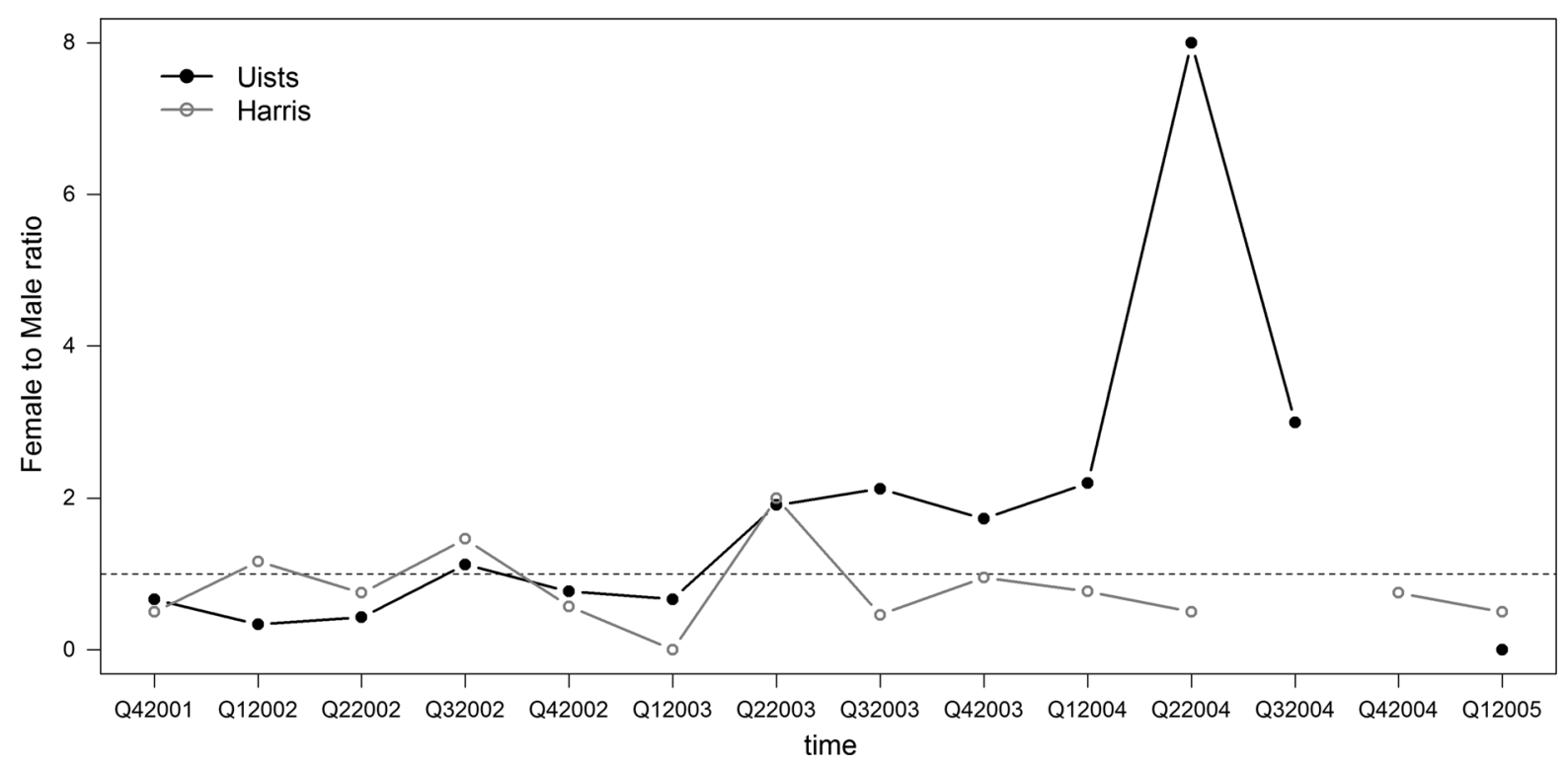

Fig. 2 Quarterly female to male ratio of captures of mink in South Harris and the Uists. Q1 corresponds to winter (January-March), Q2 to spring (April-June), Q3 to summer (July-September) and Q4 to autumn (October-December) 


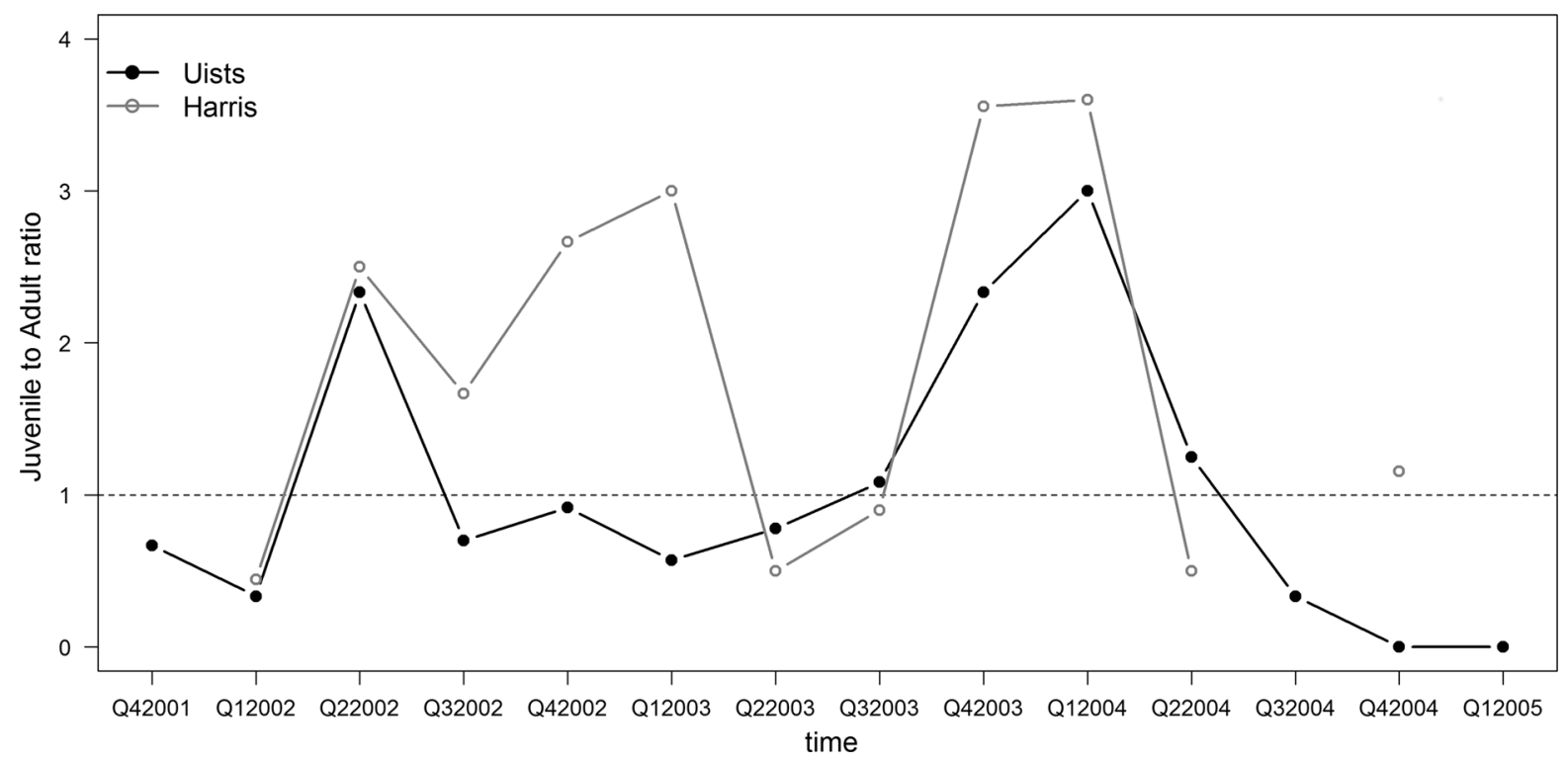

Fig. 3 Quarterly juvenile to adult ratio of captures of mink in South Harris and the Uists. Q1 corresponds to winter (January-March), Q2 to spring (April-June), Q3 to summer (July-September) and Q4 to autumn (October-December)
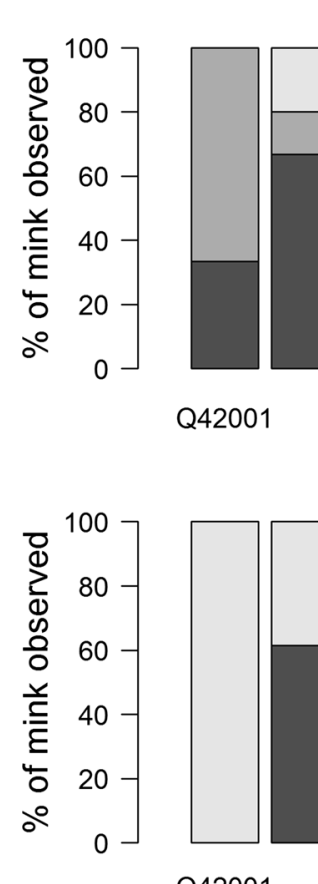
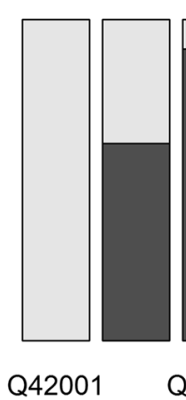
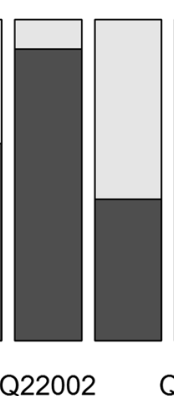
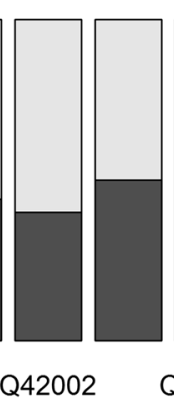

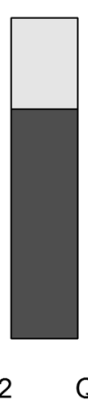

Q22003

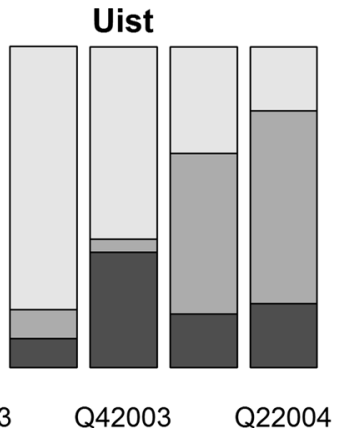

South Harris
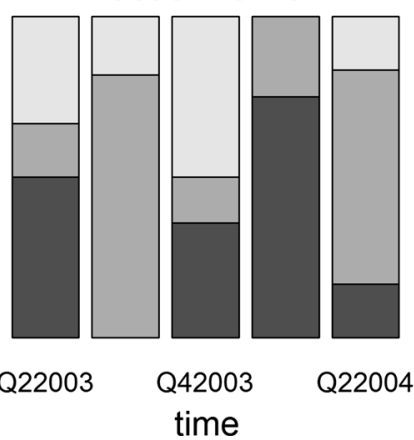

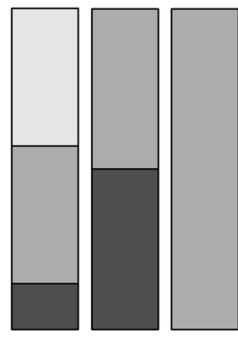

Q42004 Q22005
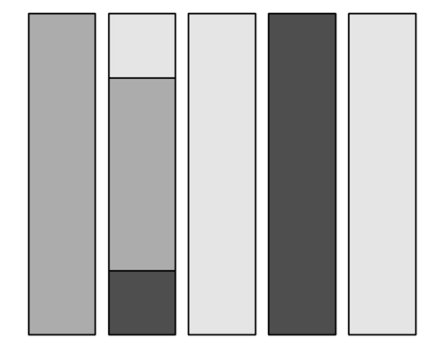

Q42004

Q22005

Q42005
Fig. 4 Quarterly percentage of captures of mink in the three habitat types on South Harris and the Uists. Captures in coastal habitats are shown in the "Coast" category; captures at lochs and rivers were pooled into one category, representing inland water ("Inland"); captures intersecting between coast and inland features, we pooled into a third category of "Mixed" habitat. Q1 corresponds to winter (January-March), Q2 to spring (April-June), Q3 to summer (July-September) and Q4 to autumn (October-December) 

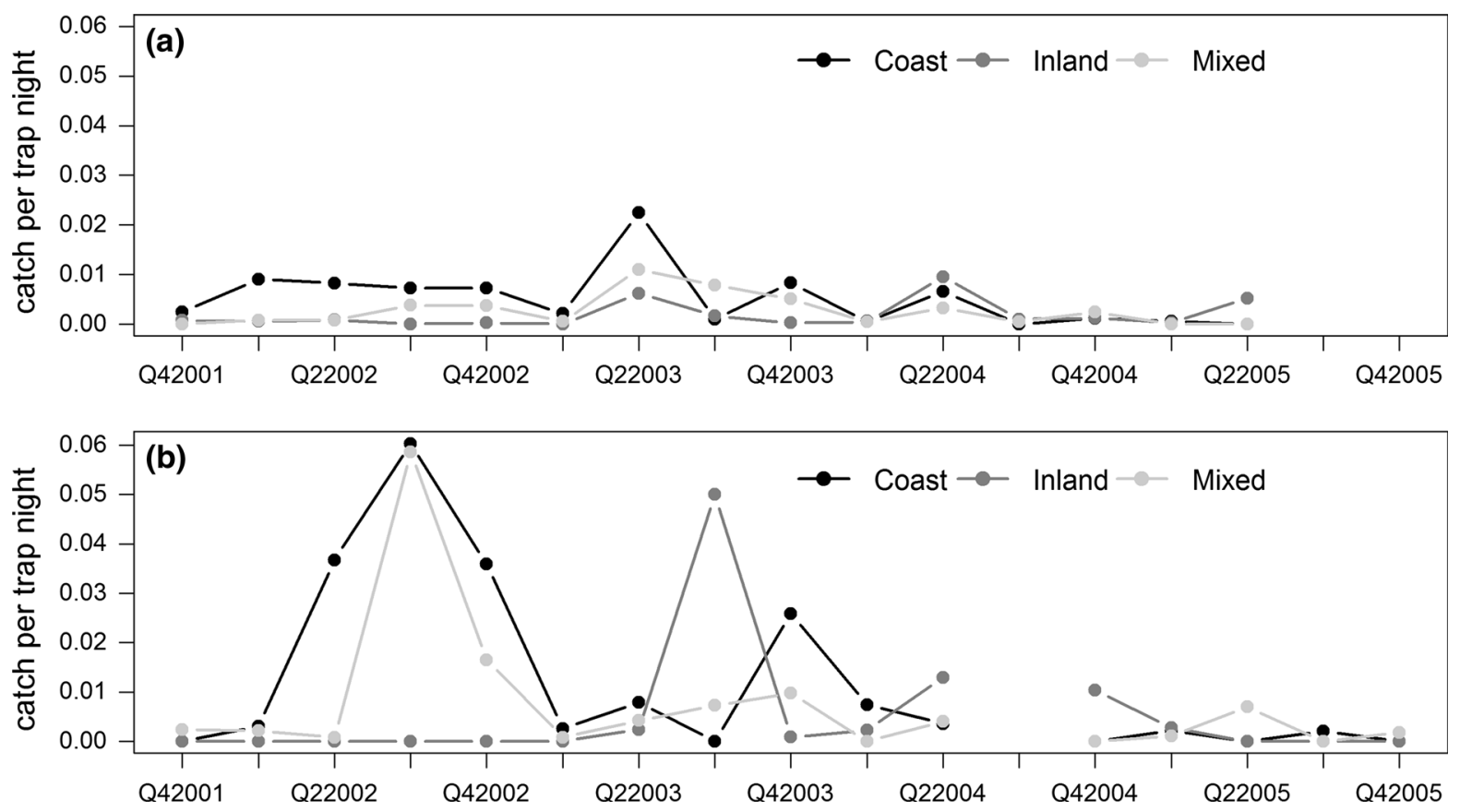

Fig. 5 Catch per effort for each island (a Uists and b South Harris) per quarter and habitat types. Some quarters had no data. Captures in coastal habitats are shown in the "Coast" category; captures at lochs and rivers were pooled into one category, representing inland water ("Inland"); captures intersecting between coast and inland features, we pooled into a third

It should be noted that there are quarters with no data (Figs. 2, 3, 4, 5) as animals were either not caught during these periods, or were caught at den sites using dog searches, and not through line trapping.

\section{Discussion}

The planning and implementation of large scale wildlife control programmes often face considerable uncertainties in the key variables needed to predict success (Roy et al. 2008). For projects aiming to remove invasive species this can typically include uncertainty about the number of animals present, the man-power required to remove each animal, how this will change as the population decreases, together with the growth rate and spatial response of the population as control proceeds. While these can all be estimated, or inferences made from other control programmes, the uncertainty will remain with potential for large effects on the likely cost and timescale for success. For control programmes of invasive species in many category of "Mixed" habitat. Q1 corresponds to winter (January-March), Q2 to spring (April-June), Q3 to summer (July-September) and Q4 to autumn (October-December). There was no significant difference in the average catch per effort per habitat between the two islands (all $p>0.18$ )

environments there may be few previous studies on which to draw. In many cases, these variables can only be reliably assessed once control is underway, requiring the adoption of an adaptive management approach (Williams 2011).

A systematic review (Tyler et al. 2005) was inconclusive in determining the effectiveness of trapping campaigns for the management of mink populations, although this did not include isolated populations, and focussed on experimental studies. As many invasive species management campaigns have limited scope to incorporate replicated experimental designs, they often rely on adaptive management for data generation (Roy et al. 2008). The study presented here clearly supported the effectiveness of trapping as a control method.

A significant challenge during eradications is to ensure all animals are exposed to traps and to account for those animals that may be unwilling to enter traps (Reynolds et al. 2004). We spaced traps to ensure each mink home range was likely to contain at least one trap and used lures to improve trapping success (Roy et al. 
2006). The ancillary use of dogs for searching reduced the potential impact of trap shyness. If trap shy animals had remained to form a breeding population, we would have expected to see juveniles appearing post-breeding, this was not the case.

The eradication of mustelids is challenging and little information was available to assess the effort required for success. This project effectively removed mink from an area of $850 \mathrm{~km}^{2}$ over 4 years using a total of 23.5 man years of effort and approximately 30 trap nights per $\mathrm{km}^{2}$ per year. It also significantly reduced mink abundance in a neighbouring $255 \mathrm{~km}^{2}$ of land using 15 man years and approximately 41 trap nights per $\mathrm{km}^{2}$ per year to reduce the risk of recolonisation from the north (Roy 2006). This northern area, covering a further $2178 \mathrm{~km}^{2}$ is the subject of a further mink eradication programme managed by Scottish Natural Heritage (Lambin et al. 2014), using the methods developed during this work.

As the work progressed a number of significant improvements were made, although their simultaneous application and declining mink numbers made it difficult to separate their individual or overall effects. These included the improvement of fine trap setting, baiting and checking, optimising trap distribution and the introduction of dogs to aid searches. These methods have helped inform the second phase of mink eradication in the remaining northern islands of the Hebrides. While this project in the Uists and South Harris was based on the use of 32 trap nights per $\mathrm{km}^{2}$ per year (only including occasions when traps were actively set to catch), the second phase has reduced this to around 14 trap nights per $\mathrm{km}^{2}$ per year with comparable savings in manpower and cost (Lambin et al. 2014).

As the project proceeded, the age and sex composition of the Uist population became more female biased and contained a smaller proportion of juveniles. For mink, like most solitary carnivore species, the males tend to be more mobile than females (Sandell 1989) and hence are more vulnerable to capture, which may account for their earlier removal. In addition, unmated female mink tend to remain on heat until mated. The remaining females may be inherently more trappable as they may be searching for mates, as seen in a number of mustelid species (Norbury 2000), and are as a result more mobile, and potentially more inquisitive with regards to artificially placed scents, and this could be exploited for landscape scale management of mink populations. The absence of free-living juveniles in the last 2 years of trapping on the Uists also supports the absence of successful breeding on the Uists in the final stages of the programme. Trapping in South Harris did not lead to eradication as this area bordered the large, uncontrolled population to the north, and the changes in sex and age ratio observed in the Uists as the population was reduced, were not repeated here. This work provided the initial phase of a larger eradication programme across the islands, As a consequence, the effort devoted to providing confidence in the total removal of the animals from the Uists was modest compared to other eradication campaigns, as it was known that work would continue after this phase was completed and the risk of animals dispersing into the cleared area remained. The second phase of this work (Lambin et al. 2014) is currently assessing the confidence in the eradication on mink throughout the Hebrides.

In both areas there was evidence of a shift in the relative trapping success in different habitats as the work proceeded. There was a relative decline in coastal trapping success through time, with a corresponding increase in loch side, and for Harris at least, riverside traps. This suggests a change in the underlying distribution of mink, possibly with them moving away from coastal areas as numbers were reduced. Previous research using stable isotope analysis (Bodey et al. 2010) suggested that animals moved away from terrestrial habitats towards marine environments as animals were removed and populations redistributed themselves. This however could not distinguish between loch and coastal environments, and for the Uists would be further confounded by the fact that many of the loch systems in the Uists are tidal and marine in nature. This could explain why the trapping returns shown here show large increases in relative capture rates at these tidal lochs (Fig. 4).

Overall this study demonstrated the value of assessing and optimising effort prior to undertaking a large and expensive eradication campaign throughout the archipelago. Understanding spatial and temporal population change in relation to trapping proved effective to monitor the progress of control efforts during an intensive pilot culling campaign. The use of an adaptive management process also ensured that improvements were adopted and built into the operating procedures as the work developed, reducing the 
effort required for the subsequent eradication campaign.

Acknowledgments The project was funded by the EU-LIFE programme, Scottish Natural Heritage, The Scottish Executive, The Royal Society for the Protection of Birds, Western Isles Council and Western Isles Enterprise. The authors would like to express gratitude to the landowners allowing access to their land and to foremen and the trappers for their hard work.

Open Access This article is distributed under the terms of the Creative Commons Attribution 4.0 International License (http:// creativecommons.org/licenses/by/4.0/), which permits unrestricted use, distribution, and reproduction in any medium, provided you give appropriate credit to the original author(s) and the source, provide a link to the Creative Commons license, and indicate if changes were made.

\section{References}

Angus S (1993) A mink control programme for Lewis and Harris. Hebrid Nat 11:78-84

Areal F, Roy SS (2006) A management decision tool for mink (Mustela vison) control in the Western Isles of Scotland (UK). J Ecodyn 40:16-41

Bilsby M (1999) Biennial report. Western Isles Fisheries Trust Bilsby M (2001) Biennial report. Western Isles Fisheries Trust Birks JDS, Linn IJ (1982) Studies of home range of the feral mink, Mustela vison. Symp Zoo Soc Lond 49:231-257

Bodey TW, Bearhop S, Roy SS, Newton J, McDonald RA (2010) Behavioural responses of invasive American mink Neovison vison to an eradication campaign, revealed by stable isotope analysis. J Appl Ecol 47:114-120

Bonesi L, Palazon S (2007) The American mink in Europe: status, impacts, and control. Biol Cons 134:470-483

Clode D, MacDonald DW (2002) Invasive predators and the conservation of island birds: the case of American Mink Mustela vison and terns Sterna spp. in the Western Isles, Scotland. Bird Stud 49:118-123

Cuthbert JH (1973) The origin and distribution of feral mink in Scotland. Mamm Rev 3:97-103

Dunstone N, Birks JDS (1983) Activity budget and habitat useage by coastal living mink (Mustela vison Schreber). Acta Zoo Fenn 174:189-191

ERM Economics (1996) Incomes study for the Western Isles. Unpublished report to Highlands and Islands Enterprise. http://www.cne-siar.gov.uk/cxdir/strategiespolicies

Ireland MC (1990) The behaviour and ecology of the American Mink Mustela vison (Schreber) in a coastal habitat. PhD thesis, University of Durham

James MA (2000) Assessing the economic value and realising the potential of recreational freshwater fisheries in the western isles. Unpublished report to Western Isles Fisheries Trust. http://www.outerhebridesfisheriestrust.org.uk/ wp-content
King CM, Edgar RL (1977) Techniques for trapping and tracking stoats (Mustela erminea): a review and a new system. NZ J Zoo 4:193-212

King CM, McDonald RM, Martin RD, Dennis T (2009) Why is eradication of invasive mustelids so difficult? Biol Cons 142:806-816

Lambin X, Cornulier T, Oliver M, Fraser EJ (2014) Analysis and future application of Hebridean Mink Project data. Commissioned Report Number 522, Scottish Natural Heritage

Moore NP, Robertson PA, Aegerter JN (2000) Feasibility study into the options for management of mink in the Western Isles. CSL, MAFF

Moore N, Roy S, Helyar A (2003) Mink (Mustela vison) eradication to protect ground-nesting birds in the Western Isles, Scotland, United Kingdom. NZ J Zoo 30:443-452

Nogales M, Vidal E, Medina FM, Bonnaud E, Tershy BR, Campbell KJ, Zavaleta ES (2013) Feral cats and biodiversity conservation: the urgent prioritization of island management. Bioscience 63:804-810

Norbury G (2000) The potential for the biological control of stoats (Mustela erminea). NZ J Zoo 27:145-163

Reynolds JC, Short MJ, Leigh RJ (2004) Development of population control strategies for mink Mustela vison, using floating rafts as monitors and trap sites. Biol Cons 120:533-543

Roy SS (2006) Mink control to protect important birds in SPAs in the Western Isles. Final Report to EU LIFE III-Nature, Scottish Natural Heritage, Edinburgh

Roy SS (2012) Strategies to improve landscape scale management of mink populations in the west coast of Scotland: lessons learned from the Uists 2001-2006. In: Veitch CR, Clout MN, Towns DR (eds) Island invasives: eradication and management. IUCN, Gland

Roy SS, Macleod I, Moore NP (2006) The use of scent glands to improve the efficiency of mink (Mustela vison) captures in the Outer Hebrides. NZ J Zoo 33:267-271

Roy SS, Smith G, Russell JC (2008) Identifying gaps in our knowledge in the management of invasive species. Hum Wildl Confl 3:30-40

Sandell M (1989) The mating tactics and spacing patterns of solitary carnivores. In: Gittleman L (ed) Carnivore behavior, ecology and evolution. Cornell University Press, New York, pp 164-182

Tyler C, Clark E, Pullin AS (2005) Do management interventions effectively reduce or eradicate populations of the American Mink, Mustela vison? CEE review 04-006 (SR7). Centre for Environmental Evidence: www. environmentalevidence.org/SR7.html

Vitousek PM, Mooney HA, Lubchenco J, Melillo JM (1997) Human domination of earth's ecosystems. Science 277:494-499

Williams BK (2011) Adaptive management of natural resources-framework and issues. J Environ Manage 92:1346-1353

Yamaguchi N, Strachan R, Macdonald DW (2002) Practical considerations for the field study of American mink Mustela vison in lowland England. Mamm Stud 27:127-133 